\title{
Revistas Capixabas publicadas na década de 1910: análises gráfica e editorial
}

\author{
Capixabas magazines published in the 1910s: graphic and editorial analysis
}

Amanda Martinelli das Neves, Letícia Pedruzzi Fonseca

revistas capixabas, análise gráfica e editorial, década 1910

O presente artigo objetivou analisar os aspectos gráficos e editoriais das quatro revistas capixabas publicadas na década de 1910: A Verdade (1912), Revista Militar da Força Pública do Estado do Espírito Santo (1912), Victoria Illustrada (1914), e Revista do Instituto Histórico e Geográfico do Espírito Santo (1917-2016). Para tanto, foi utilizado o conjunto metodológico para pesquisa em história do design a partir de materiais impressos (Fonseca et al., 2016), considerando a identificação e o tratamento da fonte primária, os exemplares disponíveis nos acervos públicos da Região Metropolitana da Grande Vitória; a coleta de dados por meio de critérios de análise pré-estabelecidos e o tratamento estatísticos dos dados para a geração de resultados a respeito de cada revista e do conjunto estudado. Os resultados obtidos por meio das características comuns e uso de recursos e técnicas recorrentes, foram relacionados ao contexto histórico e as tecnologias disponíveis, que, juntos, davam personalidade aos periódicos.

capixabas magazines, graphic and editorial analysis, 1910s

This article aimed to analyze the graphic and editorial aspects of the four Espirito Santo magazines published in the 1910s: A Verdade (1912), Revista Militar da Força Pública do Estado do Espírito Santo (1912), Victoria Illustrada (1914), and Revista do Instituto Histórico e Geográfico do Espírito Santo (19172016). For this, the methodological set was used for research in the history of design from printed materials (Fonseca et al., 2016), considering the identification and treatment of the primary source, the copies available in the public collections of the Metropolitan Region of Grande Vitória; the collection of data by means of pre-established analysis criteria and the statistical treatment of the data to generate results regarding each journal and the group studied. The results obtained through the common characteristics and the use of recurring resources and techniques, were related to the historical context and the available technologies, which, together, gave personality to the journals.

\section{Introdução}

No panorama político do Brasil, a década de 1910 foi marcada em sua fase inicial pelo governo do Presidente Marechal Hermes da Fonseca (Munteal \& Grandi, 2005). No Espírito Santo, a década foi definida pelo governo e gestão dos "Monteiros", com a seguinte ordem: Jerônimo Monteiro (1908-1912), seu tio Marcondes A. de Souza (1912-1916) e por último seu irmão Bernardino Monteiro (1916-1920) (Moreira \& Perrone, 2008). Este período caracterizou-se pelo início da modernização da capital, pois o objetivo de Jerônimo Monteiro

Anais do $10^{\circ} \mathrm{CIDI}$ e $10^{\circ} \mathrm{CONGIC}$

Kelli C.A.S. Smythe, Rafael de Castro Andrade (orgs.)

Sociedade Brasileira de Design da Informação - SBDI

Curitiba | Brasil | 2021
Proceedings of the $10^{\text {th }} \mathrm{CIDI}$ and $10^{\text {th }}$ CONGIC

Kelli C.A.S. Smythe, Rafael de Castro Andrade (orgs.)

Sociedade Brasileira de Design da Informação - SBDI Curitiba | Brazil | 2021 
era tornar Vitória o "cartão de visitas" do Estado, assim como o Rio de Janeiro era para o Brasil (Moreira \& Perrone, 2008).

Nesse contexto, temos a identificação do início da publicação de revistas no estado do Espírito Santo, com quatros publicações identificadas na década de 1910 pela pesquisa do inventário das revistas capixabas, que investigou a presença desses periódicos em acervos públicos da Região Metropolitana de Vitória, registrando mais de 300 títulos (Matos et al., 2019).

O presente artigo objetiva analisar gráfica e editorialmente as revistas capixabas publicadas na década de 1910, sendo elas: A Verdade (1912), Revista Militar da Força Pública do Estado do Espírito Santo (1912), Victoria Illustrada (1914), e Revista do Instituto Histórico e Geográfico do Espírito Santo (1917-2016). Além disso, pretende-se realizar análises comparativas entre as revistas para destacar características e técnicas comuns à época, visando correlacionar a configuração do conteúdo com o design da informação, contribuindo para os estudos da memória gráfica capixaba.

\section{Metodologia}

A pesquisa utilizou o conjunto metodológico para pesquisa em história do design a partir de materiais impressos, que se baseia em 2 etapas, sendo a primeira a aproximação do pesquisador com o contexto sócio-histórico do impresso e a segunda, a análise gráfica do mesmo.

A primeira etapa consistiu em revisão bibliográfica e, a segunda, na identificação e mapeamento de acervos; registro fotográfico; organização do acervo digital; elaboração da ficha de análise; coleta de dados; análise estatística e discussão dos resultados (Fonseca et al., 2016).

Para sistematização dos dados, observou-se título, ano de publicação, formato, preço, parque gráfico, cidade, variação cromática, capa, miolo, estrutura das páginas, tipografia, alinhamento, imagens (ilustrações pictóricas e/ou fotografias), vinhetas ${ }^{1}$ e anúncios. Para análise dos anúncios utilizou-se o método proposto por Azerêdo e Fonseca (2016), que os dividiu em tipográficos e imagéticos (Azerêdo \& Fonseca, 2016).

Os dados sobre as revistas capixabas publicadas na década de 1910, as edições disponíveis e os acervos onde estão salvaguardadas (tabela 1), foram obtidos por meio do inventário de revistas capixabas, produzido pelo Laboratório de Design: História e Tipografia (LadHT).

Os títulos da década podem ser encontrados nos acervos da Biblioteca Pública do Espírito Santo Levy Cúrcio Rocha (BPES) e do Arquivo Público do Estado do Espírito Santo (APEES), com exceção da Revista do Instituto Histórico e Geográfico do Espírito Santo que também podia ser encontrada na Biblioteca Central Fernando de Castro Moraes da Ufes (BC/ UFES), Biblioteca do Instituto Federal do Espírito Santo (IFES), Biblioteca do Instituto Jones dos Santos Neves (IJSN), Biblioteca Pública Municipal Adelpho Poli Monjardim - Vitória-ES (BPMVix) e na Biblioteca Pública Municipal Madeira de Freitas - Cariacica-ES (BPMC).

\footnotetext{
1 "Ornato tipográfico, baseado em linhas geométricas, flores, folhagens, seres vivos ou coisas inanimadas, para servir de enfeite ou cercadura em páginas de composição e trabalhos de fantasia” (Porta, 1958, p.412).
} 
Tabela 1: Revistas inventariadas produzidas no Espírito Santo durante a década de 1910, sua respectiva quantidade de edições e datas de publicação de acordo com os acervos analisados.

\begin{tabular}{|c|c|c|c|c|}
\hline $\begin{array}{l}\text { Revistas da } \\
\text { década de } 10\end{array}$ & $\begin{array}{l}\text { Acervos } \\
\text { encontrados }\end{array}$ & $\begin{array}{l}\text { Total de } \\
\text { edições* }\end{array}$ & $\begin{array}{l}\text { Total de edições } \\
\text { publicadas na } \\
\text { década de } 1910\end{array}$ & $\begin{array}{l}\text { Data de } \\
\text { publicação de } \\
\text { acordo com o } \\
\text { acervo }\end{array}$ \\
\hline A Verdade & BPES & 1 & 1 & 1912 \\
\hline $\begin{array}{l}\text { Revista Militar da } \\
\text { Força Pública do } \\
\text { Estado do Espírito } \\
\text { Santo }\end{array}$ & BPES & 1 & 1 & 1912 \\
\hline Victoria Illustrada & APEES & 1 & 1 & 1914 \\
\hline $\begin{array}{l}\text { Revista do Instituto } \\
\text { Histórico e } \\
\text { Geográfico do } \\
\text { Espírito Santo }\end{array}$ & $\begin{array}{l}\text { APEES, BPES, BC, } \\
\text { ALES, IJSN, IFES, } \\
\text { BPMVix, BPMC }\end{array}$ & 73 & 1 & $1917-2016$ \\
\hline
\end{tabular}

*O número total de edições refere-se à quantidade encontrada nos acervos inventariados e não necessariamente ao número de edições publicadas. Fonte: Autores (2021).

\section{Parque Gráfico}

Consta nas revistas estudadas a indicação de produção em três parques gráficos: Imprensa Estadual, Artes Graphicas da Victoria e Sociedade de Artes Gráphicas de Vitória, sendo que os dois últimos se tratava de apenas um, que foram apresentados com a indicação ou não de ser uma sociedade. Além disso, é preciso destacar que no período estudado o parque gráfico Artes Graphicas da Victoria utilizou as oficinas da Imprensa Estadual, que havia sido arrendada (Mattedi, 2005). Ou seja, mesmo que o parque gráfico tenha oscilado entre duas instituições diferentes, os recursos tecnológicos eram os mesmos. Esse dado indica a escassez de investimentos tecnológicos na imprensa capixaba da época e a importância da configuração visual de cada revista, com usos específicos de recursos tipográficos e investimentos em recursos visuais, como imagens e vinhetas.

\section{Análise das revistas capixabas publicadas na década de 1910}

\section{A Verdade}

Com base nos dados fornecidos no inventário do pesquisador Amâncio Pereira, publicado na Revista do Instituto Histórico e Geográfico do Espírito Santo, pode-se afirmar que se tratava de uma revista produzida na Imprensa Estadual, criada por um grupo de amigos, com o objetivo de homenagear a visita realizada em 1912 pelo então presidente do Brasil, Marechal Hermes da Fonseca, ao Estado do Espírito Santo (Pereira, 1927). 
Era apresentada em um formato de 22,5 × 30,5 cm. Sua capa era a única página com aplicação de duas cores; nela, as ilustrações pictóricas exaltam o desenvolvimento do Estado, ao ilustrar o navio no horizonte, o trem e os trabalhadores em primeiro plano, tudo isso iluminado pelo sol do "progresso". Acima disso tudo, numa moldura circular de fios duplos criando um campo reticulado, vê-se uma foto de primeiro plano de Jerônimo Monteiro (figura 1).

Figura 1: A Verdade, s/n, 1912, capa. Fonte: Acervo digital do Laboratório de Design: História e Tipografia (2020).

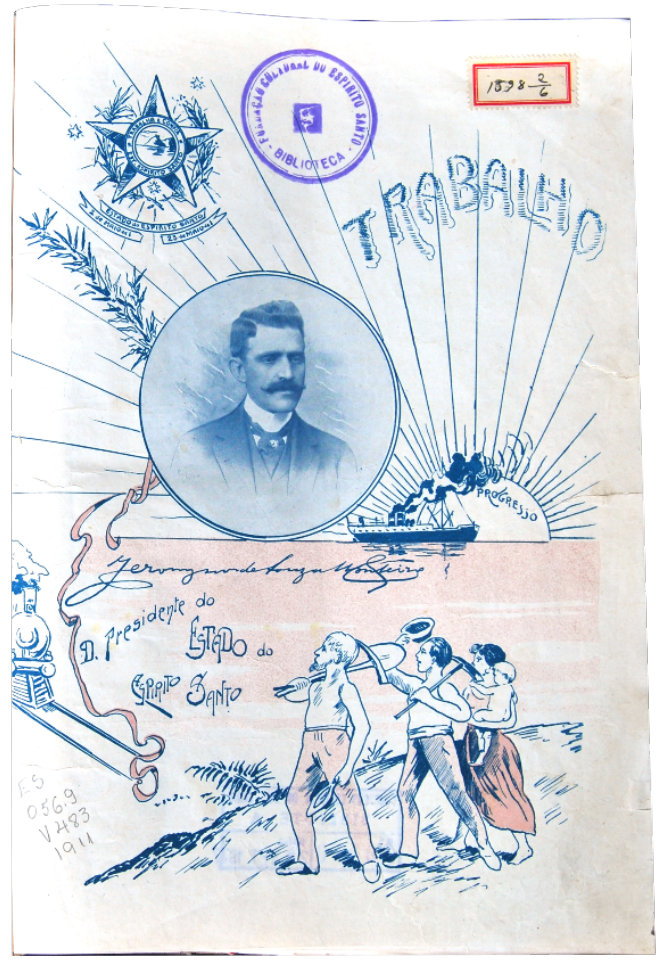

No miolo da revista, percebe-se o uso recorrente de um cabeçalho presente em todas as páginas de matérias, com o nome $A$ Verdade, em caixa alta com uma tipografia serifada em negrito em conjunto com um duplo fio como ornamento. A revista possui 42 páginas ao todo, impressão monocromática e textos alternando entre composições de uma a três colunas, comumente separadas por um fio sem espaço entre elas, com alinhamento justificado, (figura 2). 
Figura 2: A Verdade, s/n, 1912, p. 6 e 7. Fonte: Acervo digital do Laboratório de Design: História e Tipografia (2020).

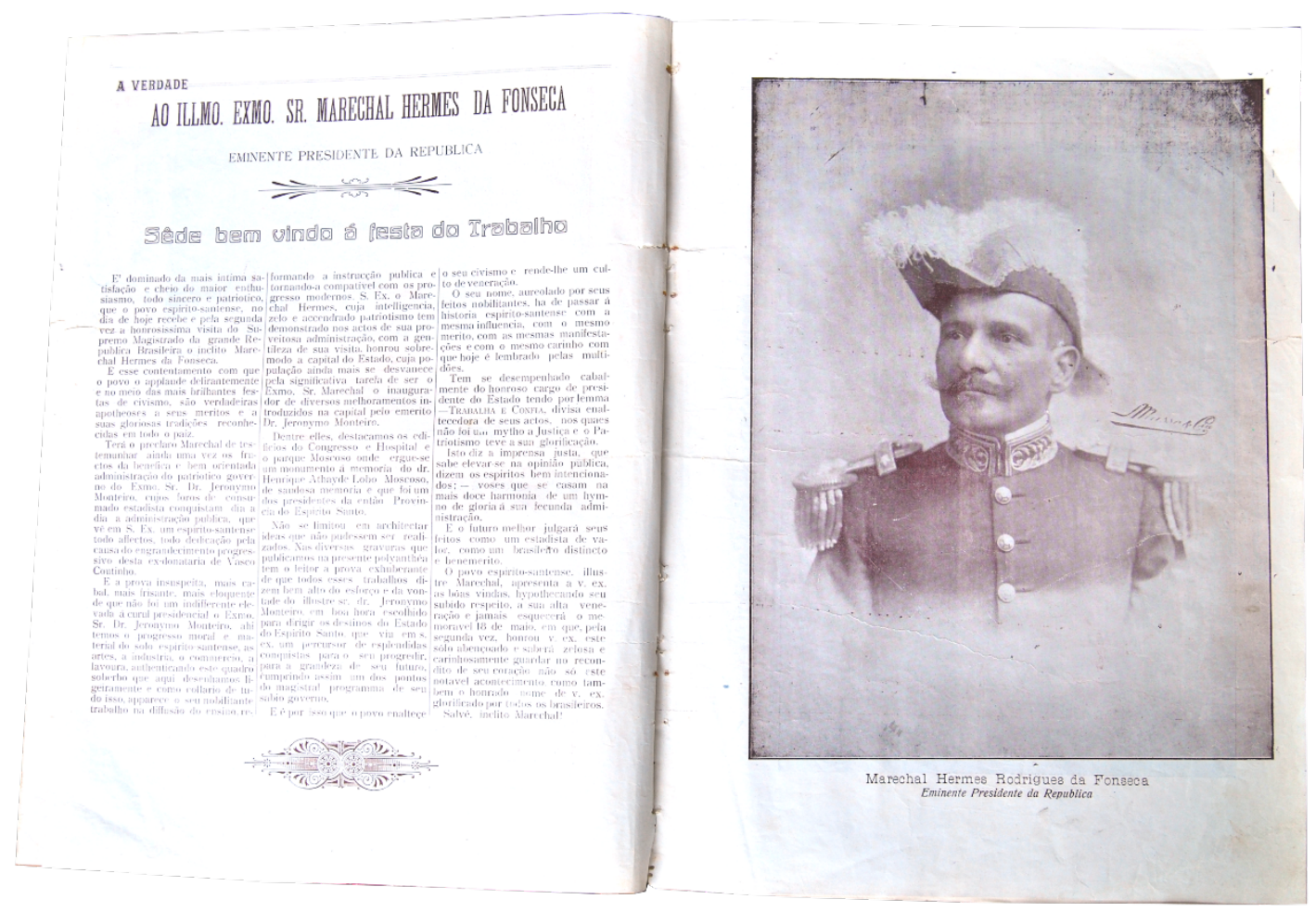

A Verdade apresentou matérias sobre a visita do então Presidente da República o Marechal Hermes da Fonseca à cidade de Vitória, além de destacar diversos melhoramentos na capital do Estado (A Verdade, s/n, 1912).

As vinhetas, assim como as fotografias, destacam-se em quase todas as páginas, seja como moldura de uma fotografia ou como parte integrante da composição de um texto. Além disso, $A$ Verdade não possui anúncios. As tipografias utilizadas tanto para o texto quanto para os títulos eram em sua maioria serifadas. Percebeu-se o uso do negrito, assim como aplicação de letras desenhadas, com o intuito de destacá-los do restante da matéria.

Com a análise de seu conteúdo, pode-se constatar que $A$ Verdade é uma revista que exalta o patriotismo, a política e o governo, assim como os feitos do presidente do Estado Jerônimo Monteiro, se caracterizando como um "convite" ao Estado, uma forma de demonstrar o desenvolvimento da capital.

Pela ausência de informações editoriais, como periodicidade e numeração da edição, por exemplo, e pelo alto investimento realizado para a produção de tantas páginas dedicadas às fotomontagens (figura 3 ) com registros das obras públicas entremeadas com imagens de figuras elitizadas e ornamentos em estilo art nouveau, pode-se supor que se trata de um álbum financiado pelo governo para a divulgação dos seus feitos. Diante do exposto, acredita-se que o formato revista deve-se ao fato de representar a modernidade pretendida pelo Governo ao financiar, junto a seus apoiadores, uma produção como essa. 
Figura 3: A Verdade, s/n, 1912, p. 20 e 21. Fonte: Acervo digital do Laboratório de Design: História e Tipografia (2020).

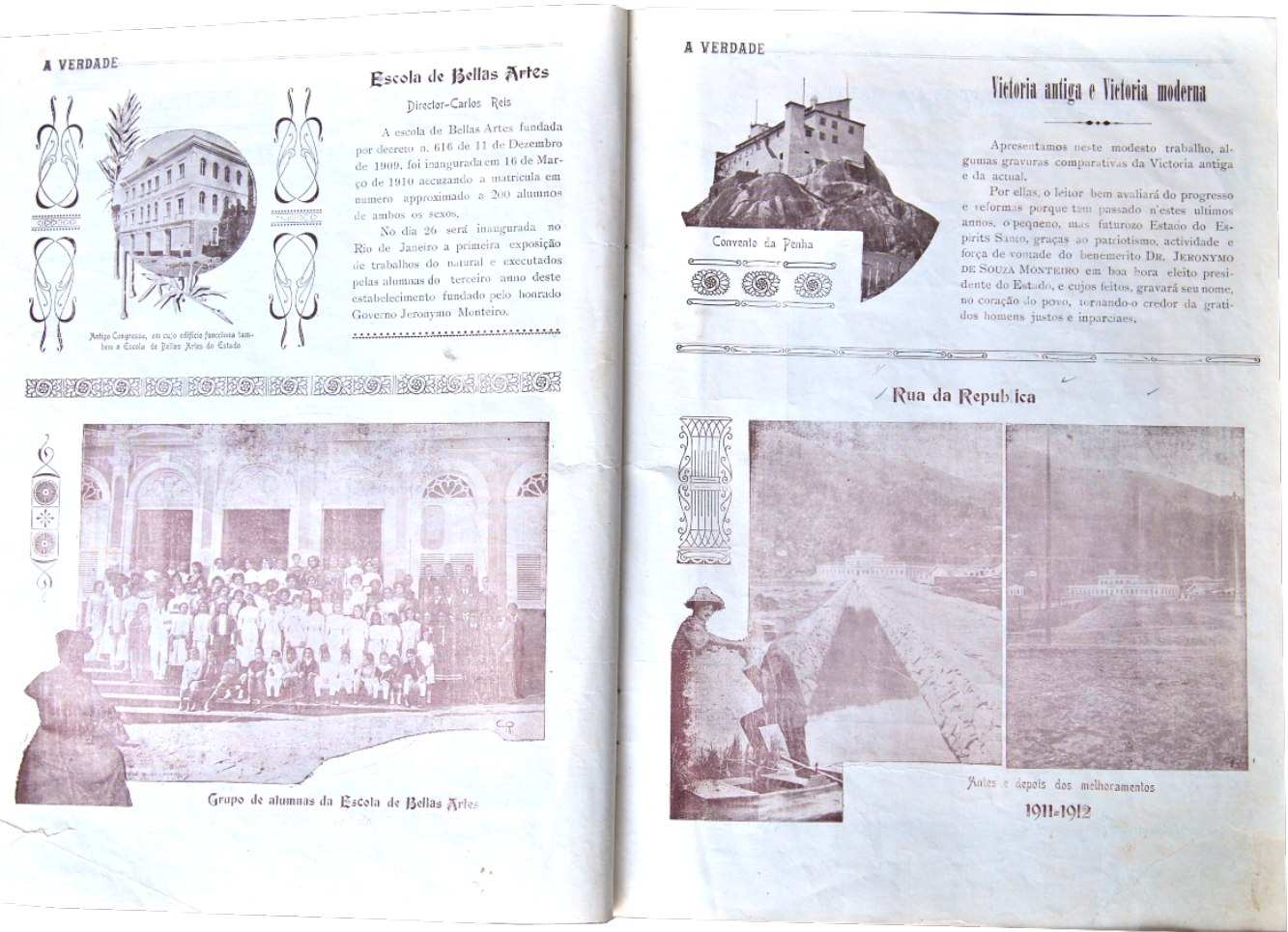

\section{Revista Militar da Força Pública do Estado do Espírito Santo}

A revista analisada é a de número 4, publicada em abril de 1912, com 20 páginas, incluindo a contagem da capa. Possui um formato de 17,9 x 25,6 cm e foi impressa na Imprensa Estadual. Sua publicação era mensal, tinha o valor avulso de $\$ 400$ réis e possuía planos de assinaturas semestrais de $2 \$ 000$ réis ou anuais de $4 \$ 000$ réis. De acordo com Pereira (1927), a revista teve apenas 5 edições, sendo a primeira publicada em janeiro de 1912, e foi fundada pelo diretor de Segurança Pública à época, Dr. Lafayette Valle e sua equipe.

A capa da Revista Militar da Força Pública do Estado do Espírito Santo utilizava a impressão em preto em um papel de coloração rosa. O título "Revista Militar" fica em destaque na parte superior com o brasão do governo do Estado do Espírito Santo separando as duas palavras. Como elementos decorativos foram utilizadas vinhetas (figura 4). 
Figura 4: Revista Militar da Força Pública do Estado do Espírito Santo, n4, abr. 1912, capa. Fonte: Acervo digital do Laboratório de Design: História e Tipografia (2020).

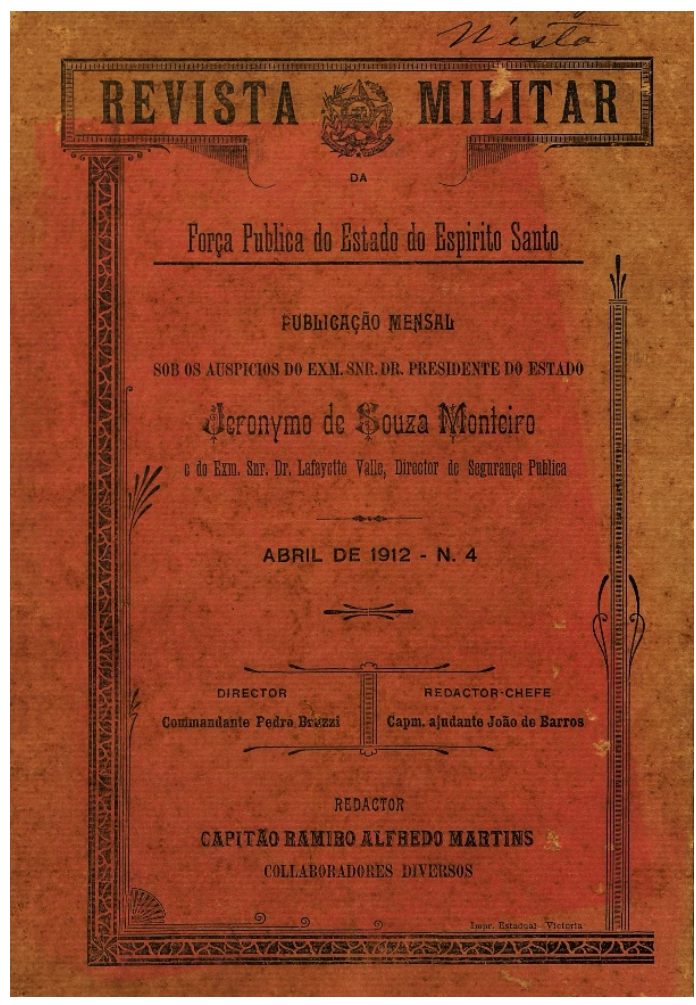

O miolo era disposto com um cabeçalho (figura 5 e 6) presente em todas as páginas de matérias, com o nome "Revista Militar" em conjunto com um duplo fio como ornamento.

Os textos eram apresentados em duas colunas com um alinhamento justificado, com exceção apenas das páginas de anúncios. Os títulos eram sempre identificados pelo uso do negrito (figuras 5 a 8). O miolo variava entre preto e branco ou monocromático (cor diferente do preto), e foram registradas fotografias, vinhetas, além de anúncios. 
Figuras 5 e 6: Revista Militar da Força Pública do Estado do Espírito Santo, n4, abr. 1912, p.9 e 13. Fonte: Acervo digital do Laboratório de Design: História e Tipografia (2020).
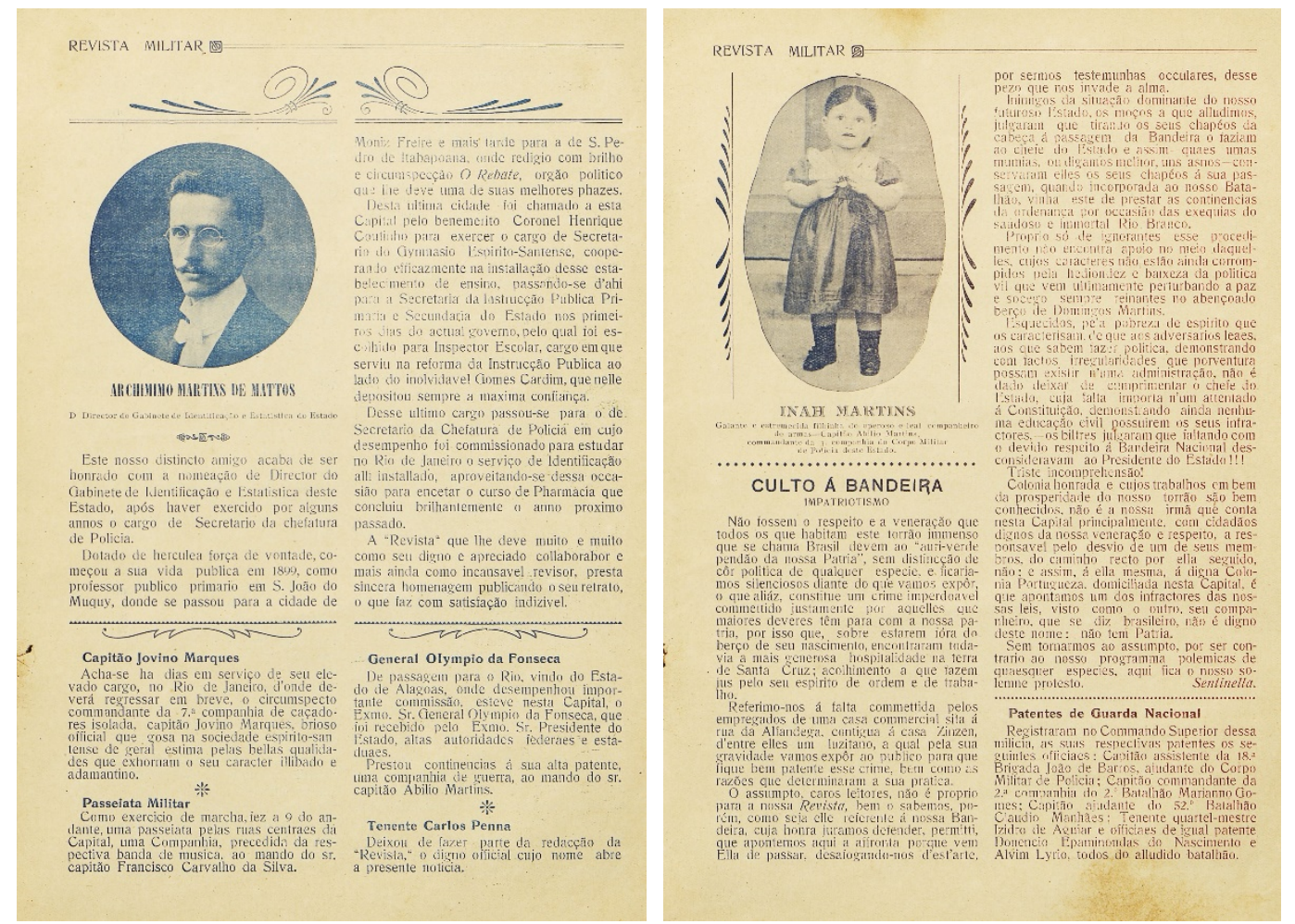

Figuras 7 e 8: Revista Militar da Força Pública do Estado do Espírito Santo, n4, abr. 1912, p.14 e 15. Fonte: Acervo digital do Laboratório de Design: História e Tipografia (2020).
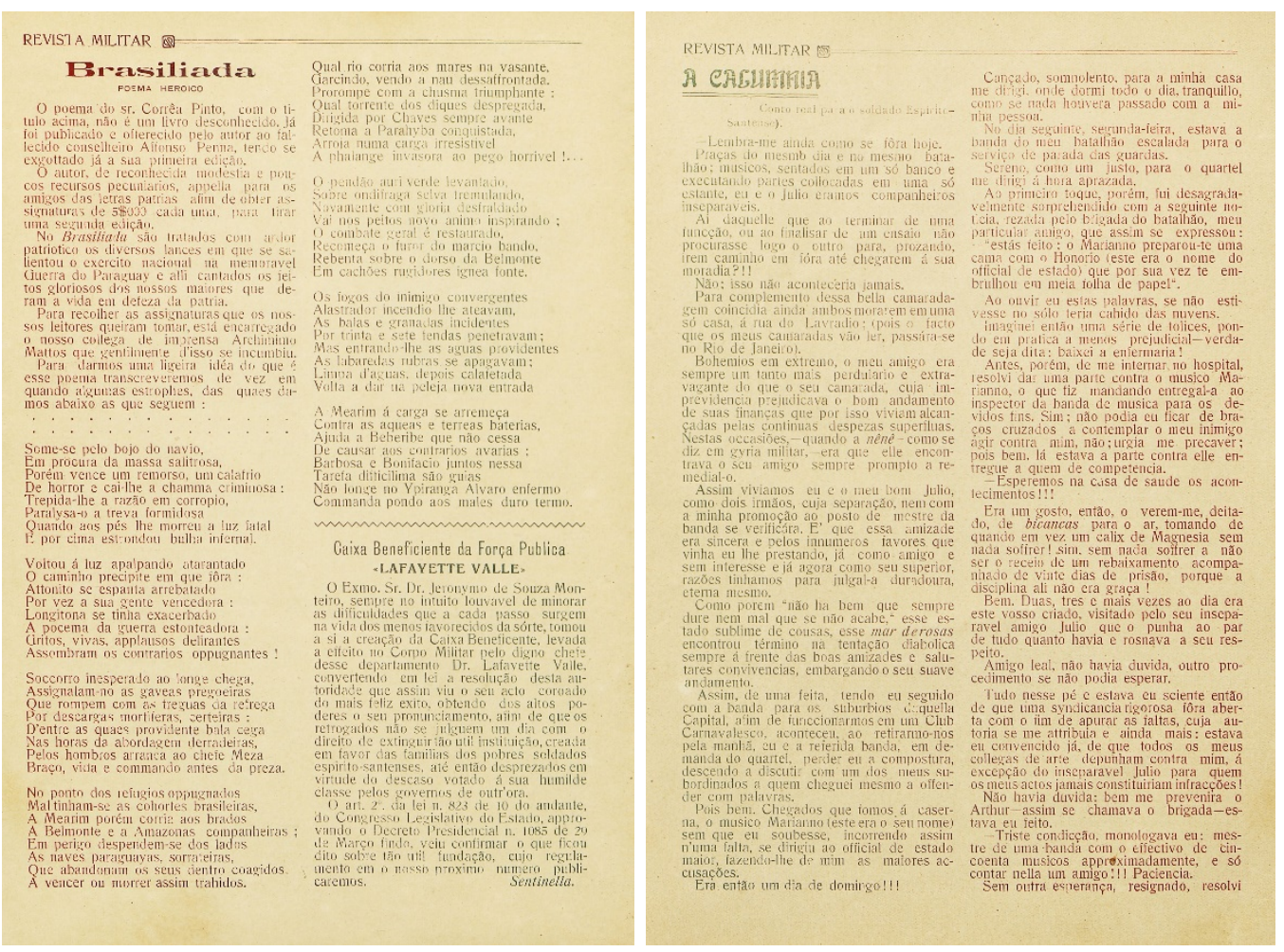
Em relação ao conteúdo da revista, foi difícil distinguir o uso de seções regulares de matérias isoladas, já que não foi empregada uma padronização do arranjo tipográfico. Além disso, o fato de não haver mais edições para análise, dificulta a confirmação do uso dessa setorização editorial (Revista Militar da Força Pública do Estado do Espírito Santo, n. 4, abr. 1912).

A tipografia utilizada variava entre com e sem serifa, sendo a primeira amplamente empregada nos textos e títulos e a segunda usada com menos frequência, como no título "Culto á Bandeira" (figura 6) (Revista Militar da Força Pública do Estado do Espírito Santo, n. 4, abr. 1912).

$\mathrm{Na}$ edição analisada foram publicados sete anúncios, sendo encontrados apenas nas áreas das capas (figuras 9 a 11): a da "Casa Miranda", "Sapataria Syria" e "Casa Mascote" (segunda capa), "A Primavera" e "Alfaiataria Smart" (terceira capa) e por último "Alfaiataria Resemini" e "Café Rio Branco" (quarta capa).

Foram verificados seis anúncios tipográficos e um anúncio imagético. $O$ anúncio imagético é o da "Casa Mascote", este faz uso de uma ilustração pictórica como recurso visual, apresentando uma mulher bem trajada segurando uma placa com o nome do estabelecimento que vendia apenas artigos masculinos.

Identificou-se também anúncios classificados como tipográficos, estes utilizavam diferentes tipografias com o objetivo de chamar atenção do leitor para determinadas informações, como nome do estabelecimento, produto e local, cada um em uma "ordem" diferente de leitura, auxiliado pelo uso do negrito, caixa alta e tamanho, além de vinhetas como elementos decorativos.

Figura 9: Revista Militar da Força Pública do Estado do Espírito Santo, $n^{\circ} 4$, abr. 1912, segunda capa. Fonte: Acervo digital do Laboratório de Design: História e Tipografia (2020).

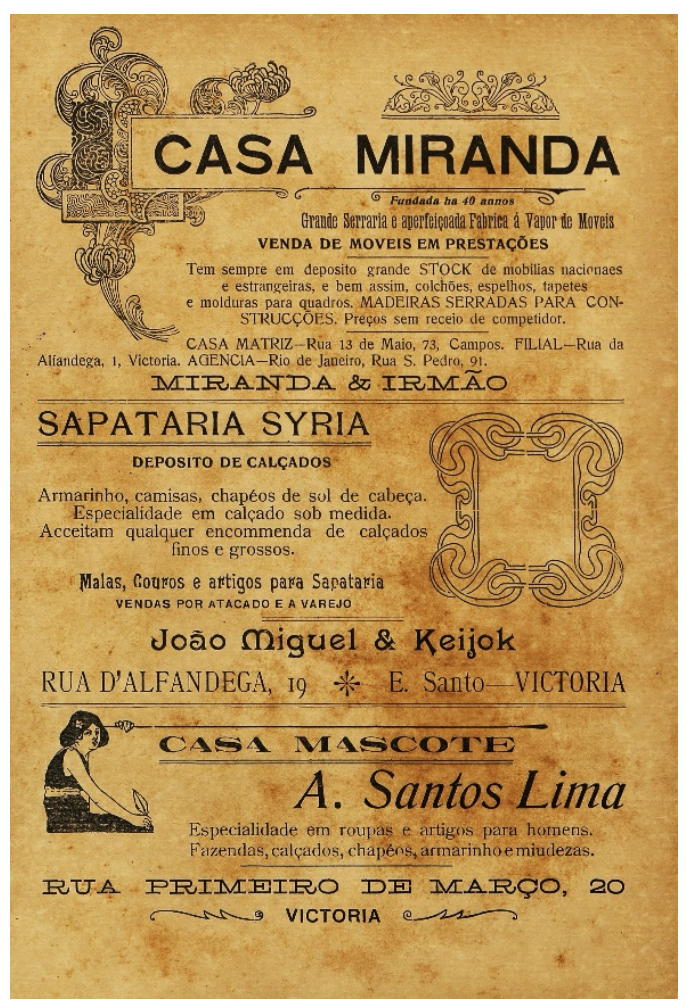


Figuras 10 e 11: Revista Militar da Força Pública do Estado do Espírito Santo, n4, abr. 1912, terceira e quarta capa. Fonte: Acervo digital do Laboratório de Design: História e Tipografia (2020).
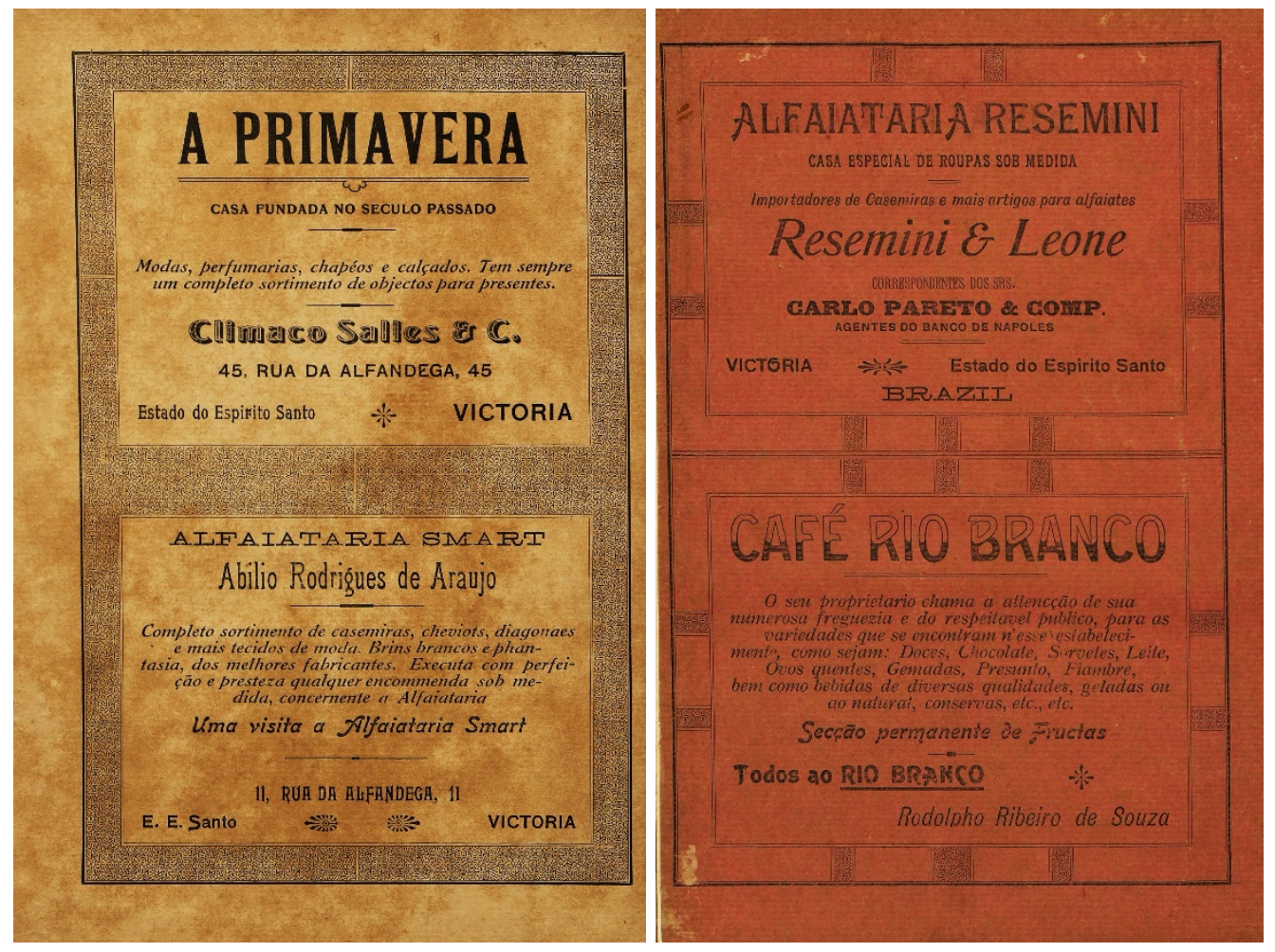

Após a verificação do planejamento e configuração gráfica da revista, podemos afirmar que a revista era destinada a um público masculino e militar, além disso era fortemente influenciada pelo contexto histórico da época simbolizado pela política do Presidente Marechal Hermes da Fonseca.

\section{Victoria Illustrada}

A revista analisada é a quarta edição, de 1914. Impressa no parque gráfico da Sociedade de Artes Gráphicas de Vitória, seu redator proprietário era Francisco Barbosa de Souza. Victoria Illustrada tinha uma periodicidade quinzenal, sendo comercializada a $\$ 400$ réis o exemplar avulso ou $10 \$ 000$ réis uma assinatura anual, com um formato de 22,5 x 29,5 cm (Victoria Illustrada, ano $1, n^{\circ} 4$, fev. 1914).

O periódico não possuía uma folha de expediente e, quando havia alguma menção do redator no texto, geralmente se localizava ao final das matérias. Em relação ao seu conteúdo averiguou-se que ela era composta por textos literários, como contos e poemas.

A capa da revista é marcada pela aplicação de duas cores. Ela inicia com um cabeçalho em que informações sobre o ano estão à esquerda, número da edição à direita e os dizeres "Não tem política" ao centro. O título Victoria Illustrada ocupa um espaço horizontal considerável da mancha gráfica. Logo depois, centralizados, estão sua periodicidade e o nome do redator proprietário. Ao final, há uma fotografia em plano geral do Parque Moscoso, com o uso de vinhetas decorativas na parte superior e inferior da mesma (figura 12). 
Figura 12: Victoria Illustrada, ano 1, n4, fev. 1914, capa. Fonte: Acervo digital do Laboratório de Design: História e Tipografia (2020).

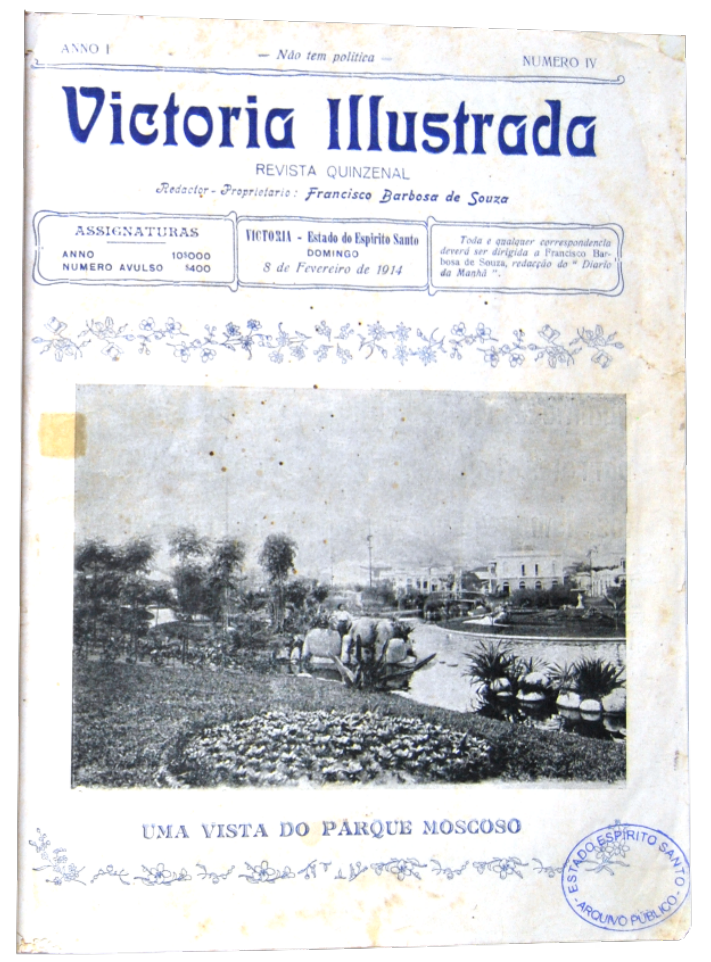

A revista apresenta miolo em preto e branco e impressão monocromática, com cor diferente do preto, na capa e quarta capa. O miolo se organiza com um cabeçalho presente na maioria das páginas, composto com o nome da revista, o número da página, em conjunto com uma série de vinhetas (figura 13). 
Figura 13: Victoria Illustrada, ano 1, n4, fev. 1914, p.4 e 5. Fonte: Acervo digital do Laboratório de Design: História e Tipografia (2020).

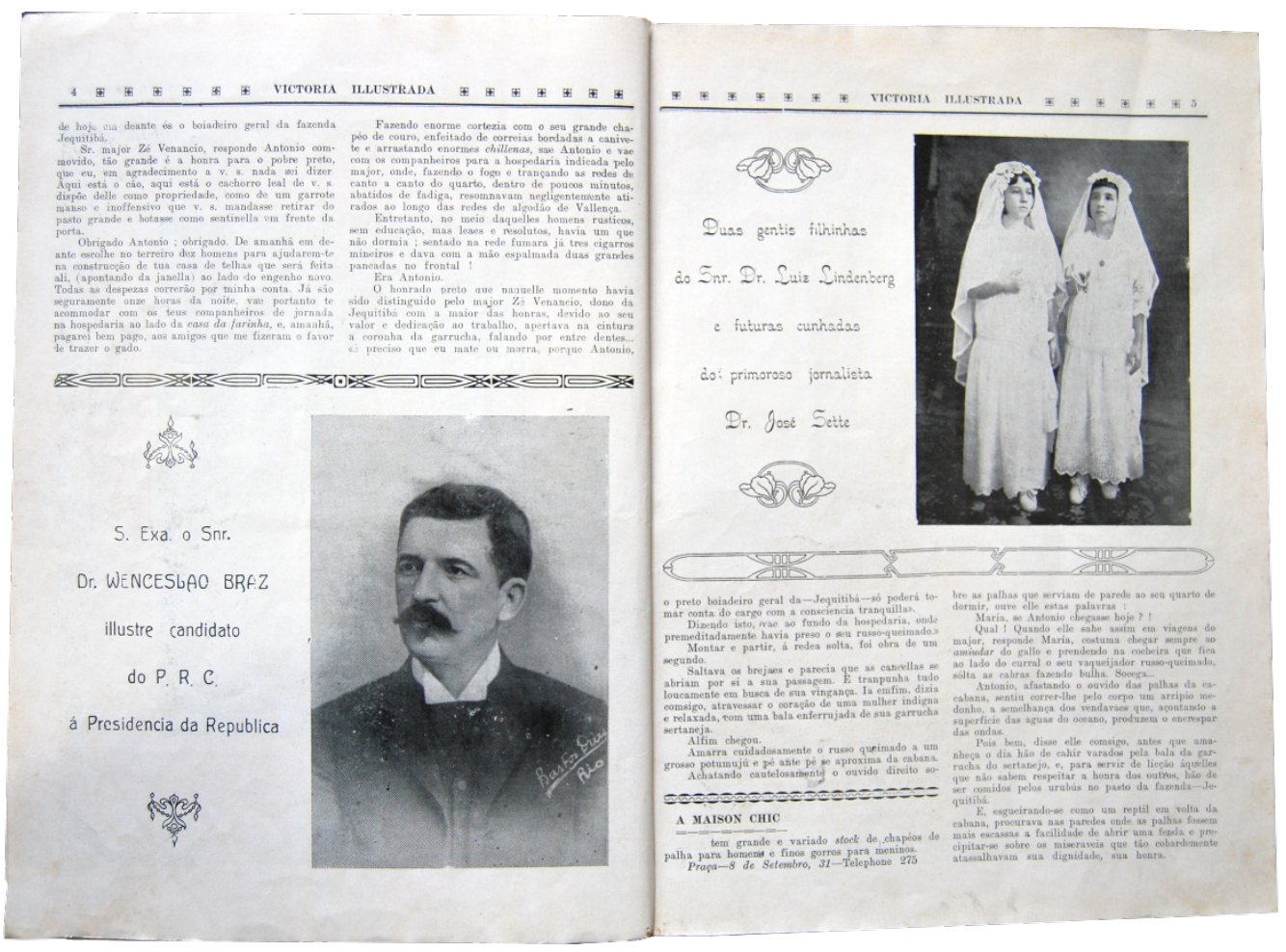

A estrutura das páginas da revista era configurada com blocos de textos de duas colunas separadas com um espaço entre elas, alinhamento justificado com um pequeno recuo na primeira linha e o uso de uma fonte serifada. Os elementos gráficos registrados são as fotografias, ilustrações pictóricas e vinhetas.

Os anúncios que utilizavam uma página, são em sua maioria tipográficos do tipo ornamentados, com vinhetas decorativas e arabescos, como o do "Hotel Internacional José Ferreira Bento" (figura 14), seguido dos imagéticos, como o do "João Carriol relojoaria e joalheria" que possui uma ilustração de relógio (figura 15) e o da "Casa dos Viajantes" (figura 16), em que há o recorte de uma foto referente a um conjunto de mobílias. 
Figura 14: Victoria Illustrada, ano 1, n4, fev. 1914, p. s/n 3. Fonte: Acervo digital do Laboratório de Design: História e Tipografia (2020).

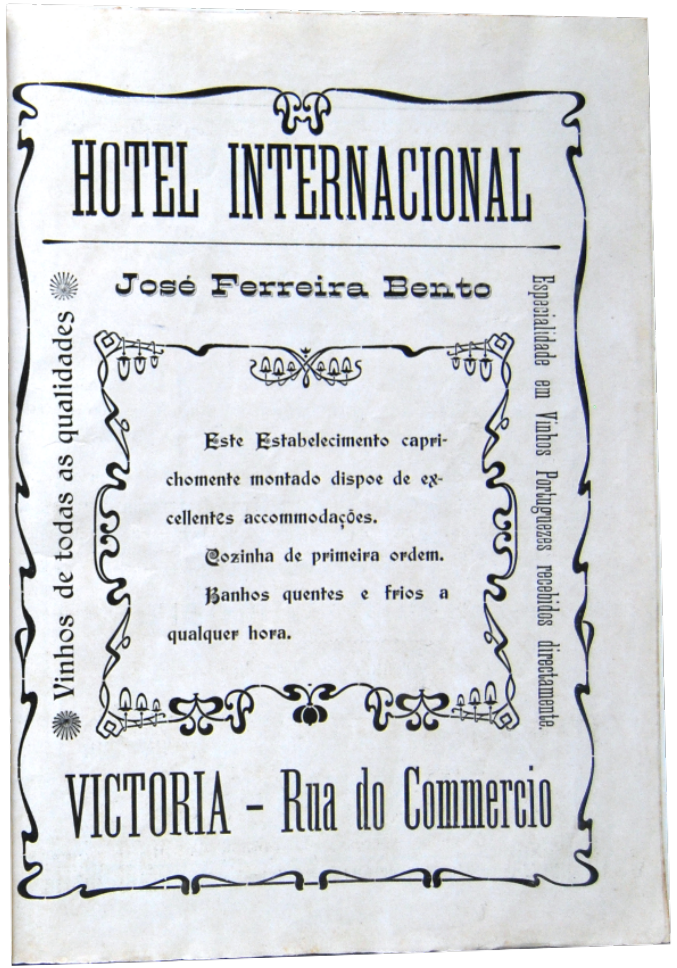

Figura 15: Victoria Illustrada, ano 1, n4, fev. 1914, p. s/n 2. Fonte: Acervo digital do Laboratório de Design: História e Tipografia (2020).

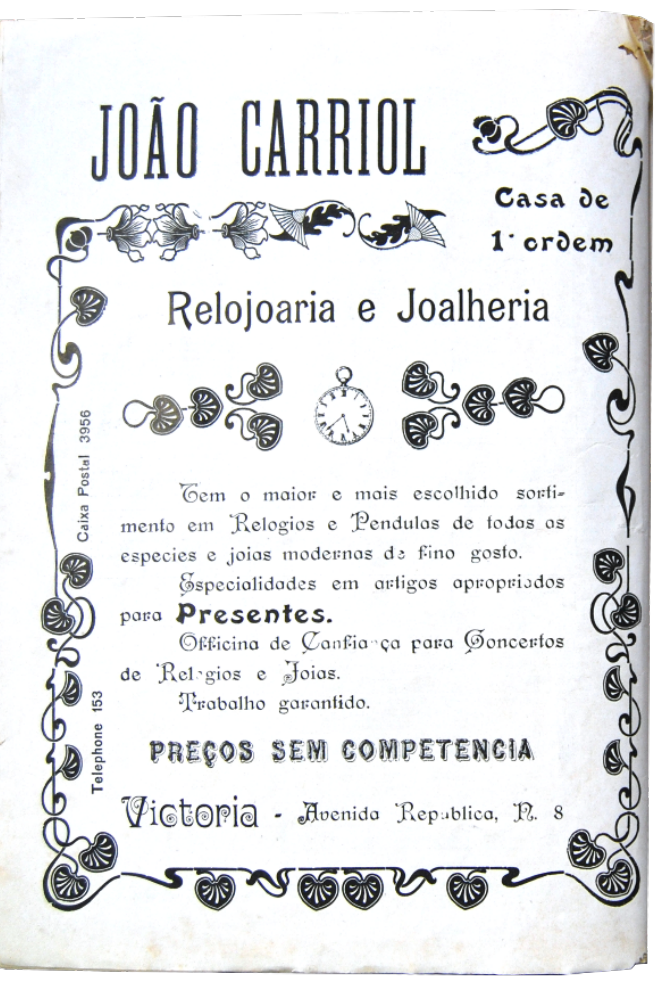


Figura 16: Victoria Illustrada, ano 1, n4 fev. 1914, p. s/n 4 e terceira capa. Fonte: Acervo digital do Laboratório de Design: História e Tipografia (2020).

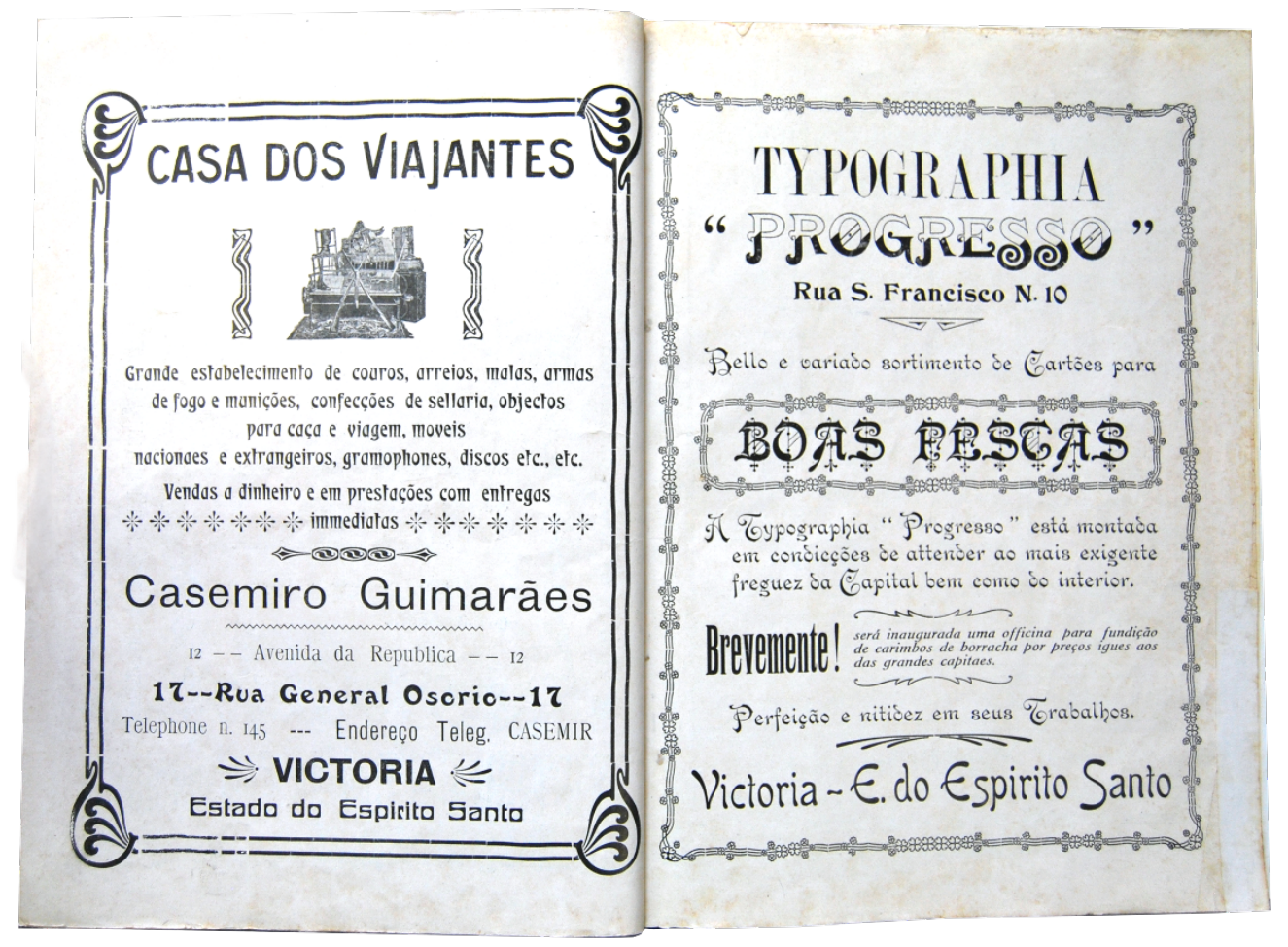

Há uma grande variação no tamanho dos tipos presentes ao longo dos anúncios, principalmente nos anúncios tipográficos, que se empenham em composições que preenchem os espaços disponíveis, além de estabelecer um arranjo recorrente para a organização das informações, com o uso de negrito, caixa alta, e variação no tamanho da fonte e tipos.

Os anúncios da revista se assemelham aos impressos do século XIX que utilizavam diferentes estilos, tipografias e vinhetas decorativas, euforia possibilitada pela era industrial que viabilizou a criação de novas tecnologias, modernizando os meios de comunicação e a concepção de novos estilos tipográficos (Meggs \& Purvis, 2009).

Apesar de a revista apresentar em sua primeira página os dizeres: "Não tem politica", há muitas fotografias relacionadas às autoridades e figuras políticas. A revista também se destaca por sua variedade de vinhetas utilizadas, tanto como decoração, quanto como recurso auxiliar da informação, ao ser empregado separador de conteúdo

\section{Revista do Instituto Histórico e Geográfico do Espírito Santo}

Esta revista possui apenas um exemplar na década de 1910 sendo este o de sua edição inaugural, em 1917. Não possuía valores de vendas em suas páginas, era de caráter institucional, histórico e geográfico, tendo a construção da memória histórica capixaba como um dos principais objetivos do Instituto e seus associados (Moreira \& Perrone, 2008). Sua periodicidade variou ao longo das décadas, tendo a última edição sido publicada em 2016. Seu formato era, de acordo com Pereira (1927, p.142), "150 X 218 mm". 
A capa desta primeira edição se difere de suas edições posteriores, pois esta apresenta uma ilustração do Convento de Nossa Senhora da Penha, contido em uma forma circular com traços simples, algumas molduras decorativas em estilo art nouveau (figura 17).

Figura 17: Revista do Instituto Histórico e Geográfico do Espírito Santo, ano I, $\mathrm{n}^{\circ} \mathrm{I}$, 1917. Fonte: Acervo digital do Laboratório de Design: História e Tipografia (2020).

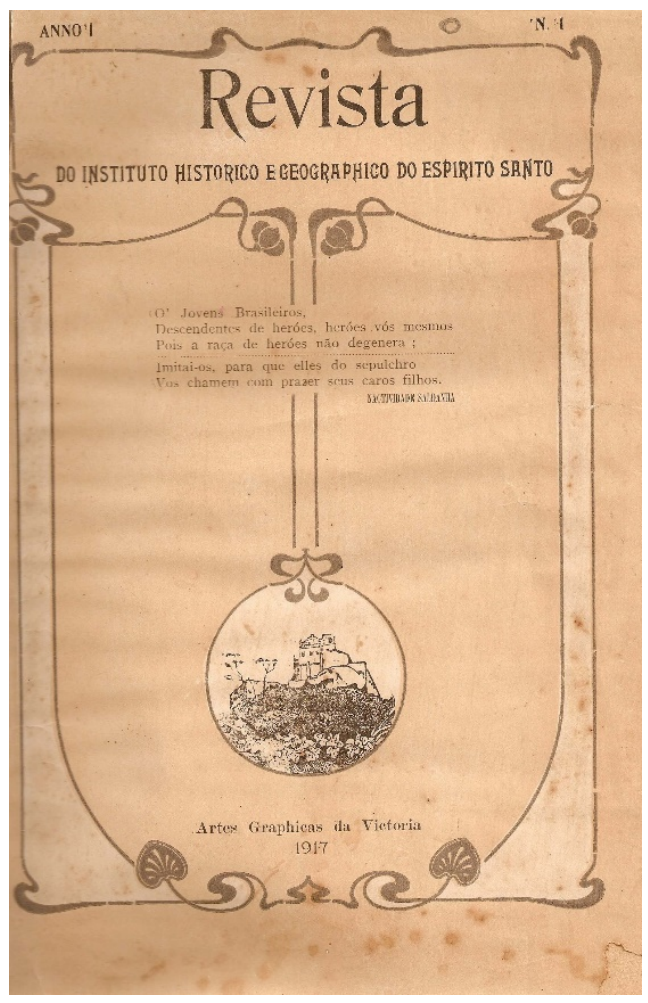

O miolo da primeira e segunda edições variava um pouco, fato que pode ser justificado pela mudança na presidência de Antonio Francisco Athayde para Archimimo Martins e pelo período de hiato entre as edições (Pacheco et al., 2011).

Ao longo das páginas vemos textos com alinhamento justificado, a página estruturada em uma ou duas colunas de texto com uma calha de respiro entre elas. A tipografia é serifada e, para fins de hierarquização, o negrito e o itálico costumam ser empregados nos títulos com uma variação entre caixa alta e baixa (figura 18). 
Figura 18: Revista do Instituto Histórico e Geográfico do Espírito Santo, ano I, n I, 1917, p. 7. Fonte: Acervo digital do Laboratório de Design: História e Tipografia (2020).

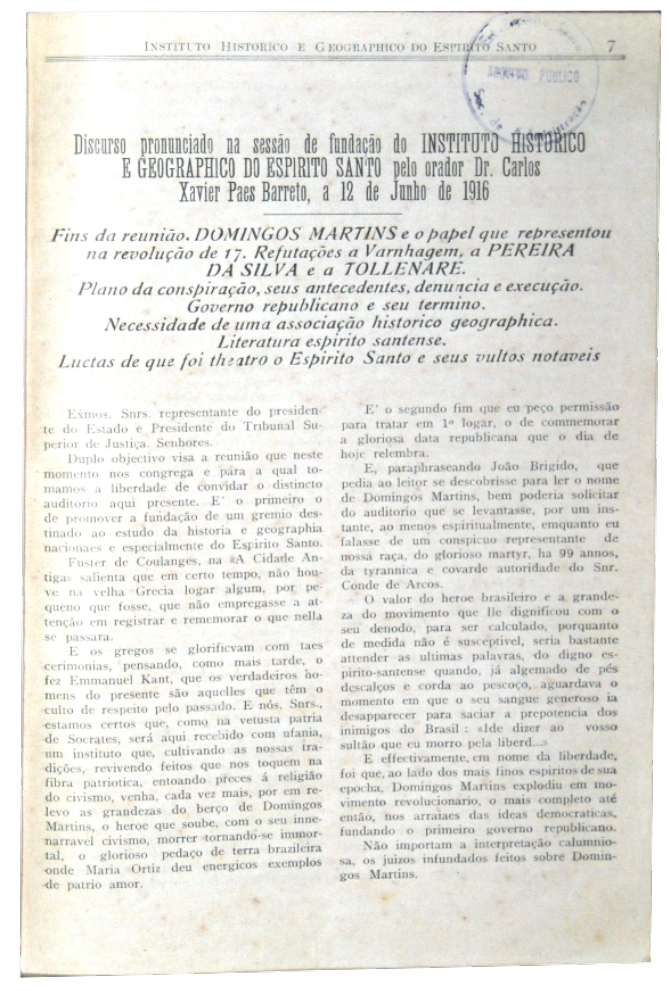

Há vários textos ao longo da publicação, estes normalmente eram atas de reuniões do instituto, textos históricos, documentos e artigos. Como se pode observar, o Instituto Histórico e Geográfico do Espírito Santo (IHGES) é uma fonte rica de informações, além de ser um material de preservação da memória capixaba (Revista do Instituto Histórico e Geográfico do Espírito Santo, ano 1, n. 1, 1917).

O que mais se destacou nesta edição foi a presença de uma única foto em plano americano de Domingos Martins, que ocupa mais de $50 \%$ da página, contida em uma moldura na cor verde com os dizeres: "Ide dizer ao vosso sultão que eu morro pela liberd..." (Revista do Instituto Histórico e Geográfico do Espírito Santo, ano 1, n. 1, 1917, p. 17) escritos na parte inferior da página aplicado em moldura no estilo art nouveau (figura 19). 
Figura 19: Revista do Instituto Histórico e Geográfico do Espírito Santo, ano I, n I, 1917, p. 17. Fonte: Acervo digital do Laboratório de Design: História e Tipografia (2020).

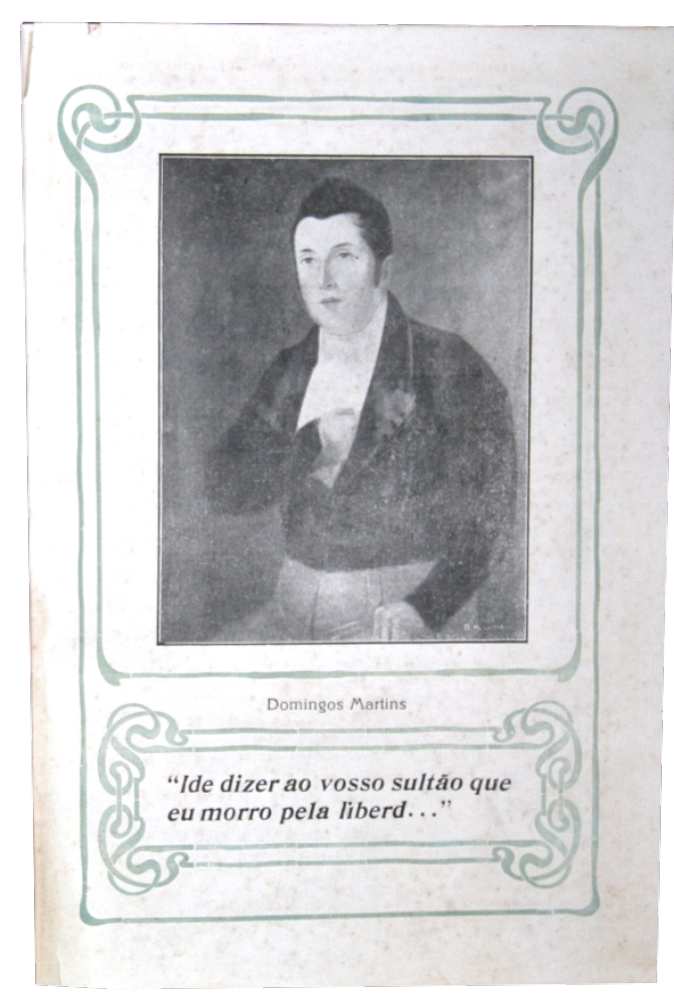

Ao analisar a edição inaugural da Revista do Instituto Histórico e Geográfico do Espírito Santo percebe-se que ela é basicamente composta por conteúdo textual, sem muitas experimentações gráficas. Ela se configura como um livro e se posiciona como fonte de conhecimento ao expor artigos e documentos históricos.

\section{Resultados}

A partir da coleta de dados realizada com a fonte primária, foi possível conhecer as características gerais da configuração gráfica das revistas capixabas, conforme disposto na tabela 2 e figuras 20 a 24, além de informações como parque gráfico, quantidade de páginas, preço, cidade (tabela 3), como também verificar aspectos relacionados à composição do miolo (tabela 4). 
Tabela 2: Disposição das revistas e de seus elementos gráficos, de acordo com as edições publicadas na década de 1910.

\begin{tabular}{llll}
\hline Revista & $\begin{array}{l}\text { Variação cromática da } \\
\text { capa }\end{array}$ & $\begin{array}{l}\text { Variação cromática do } \\
\text { miolo }\end{array}$ & Elementos gráficos \\
\hline A Verdade & duas cores & monocromático & $\begin{array}{l}\text { Lettering na capa, } \\
\text { fotografias, vinhetas } \\
\text { decorativas, } \\
\text { ilustrações pictóricas }\end{array}$ \\
\hline $\begin{array}{l}\text { Revista Militar da } \\
\text { Força Pública do }\end{array}$ & preto e branco & & Fotografias, vinhetas \\
$\begin{array}{l}\text { Santo do Espírito } \\
\text { Victoria Illustrada }\end{array}$ & duas cores & monocromático/ preto e & branco \\
\hline $\begin{array}{l}\text { Revistárico e } \\
\text { Geográfico do } \\
\text { Espírito Santo }\end{array}$ & monocromático/ preto e & Fotografias, \\
\hline
\end{tabular}

Fonte: Autores (2021).

Figura 20: Infográfico da revista A Verdade com suas principais características e elementos gráficos.

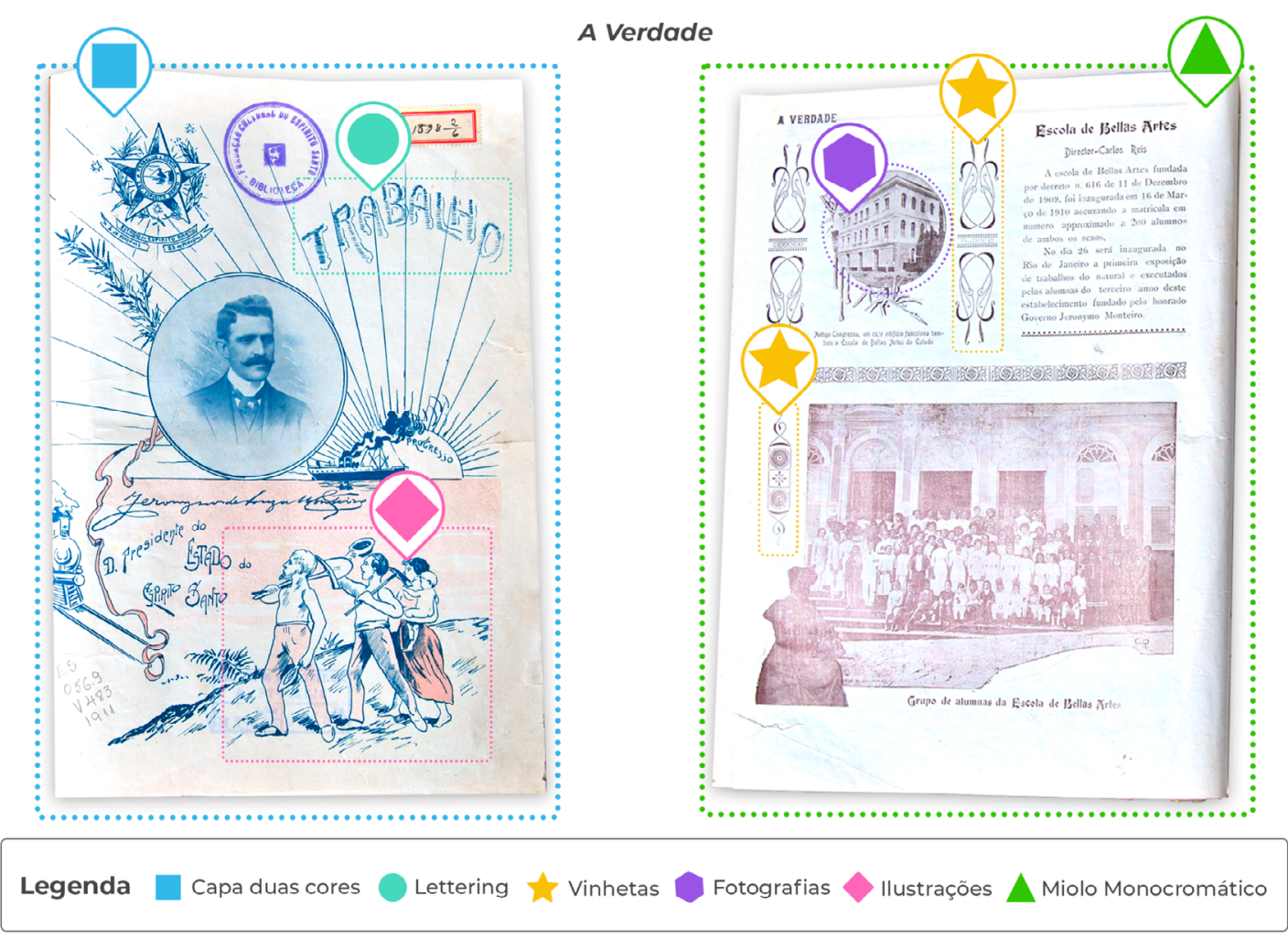


Figura 21: Infográfico da Revista Militar da Força Pública do Estado do Espírito Santo com suas principais características e elementos gráficos.

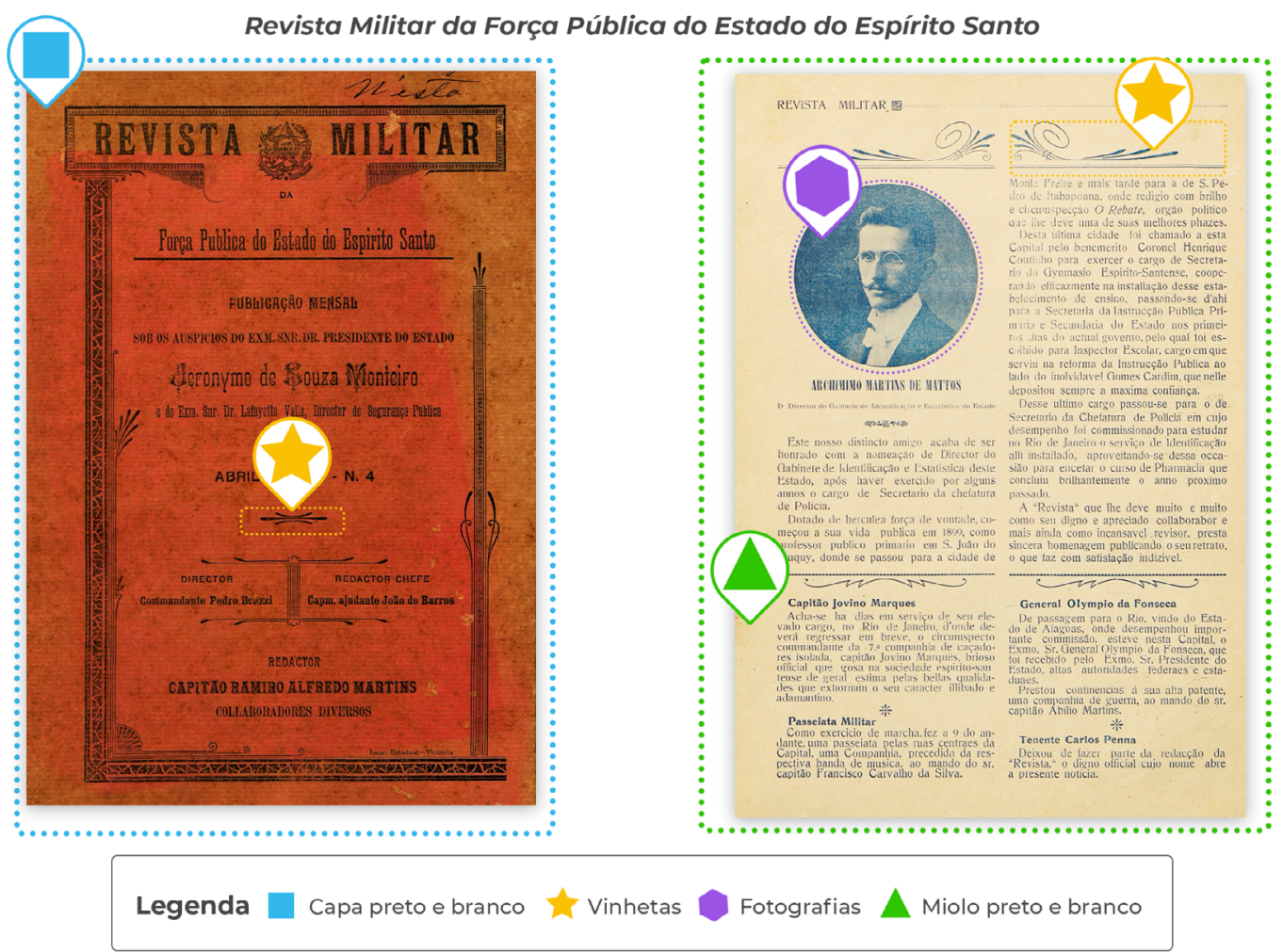

Figura 22: Infográfico da revista Victoria Illustrada com suas principais características e elementos gráficos.

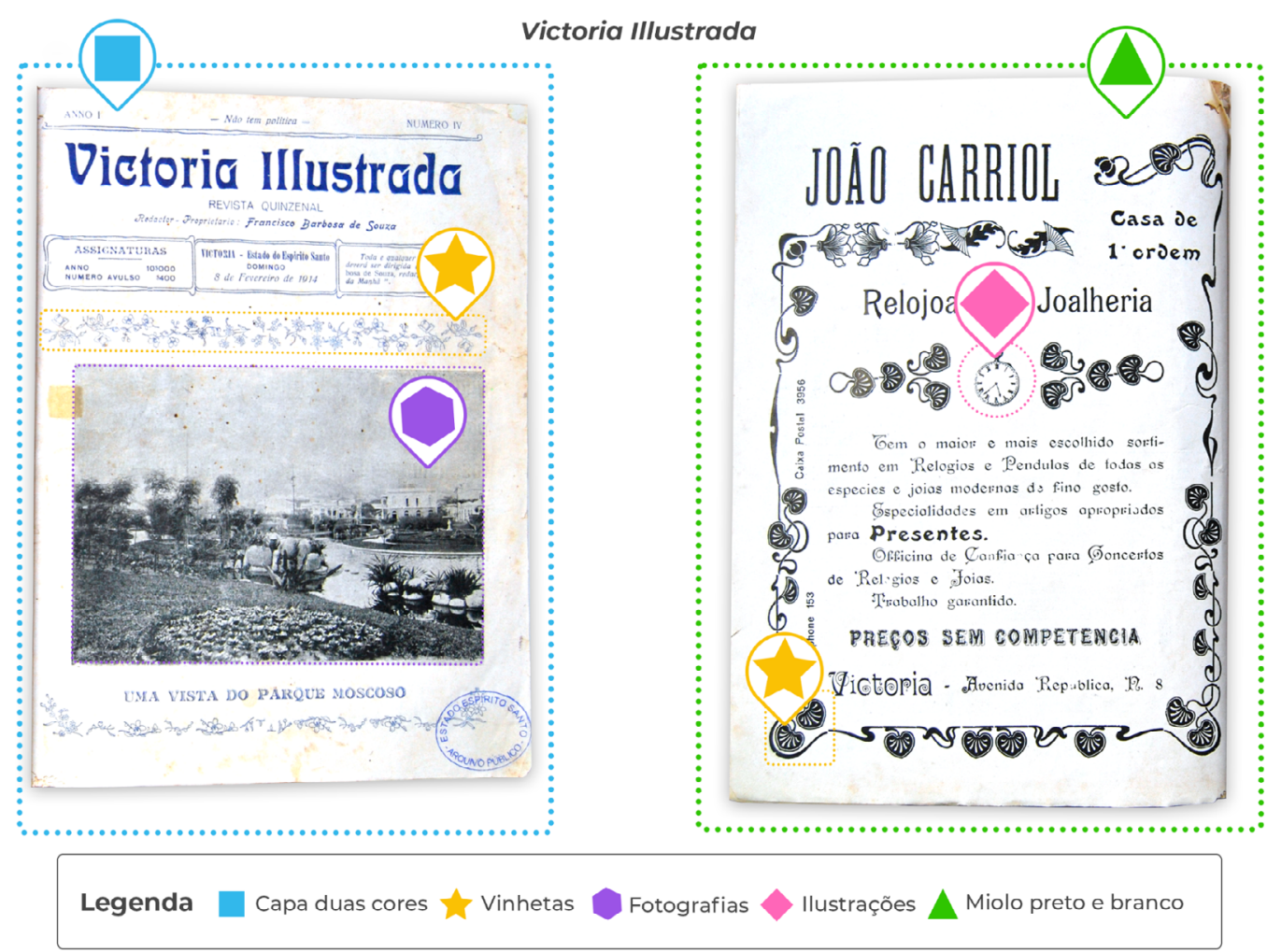


Figura 23: Infográfico da Revista do Instituto Histórico e Geográfico do Espírito Santo com suas principais características e elementos gráficos.

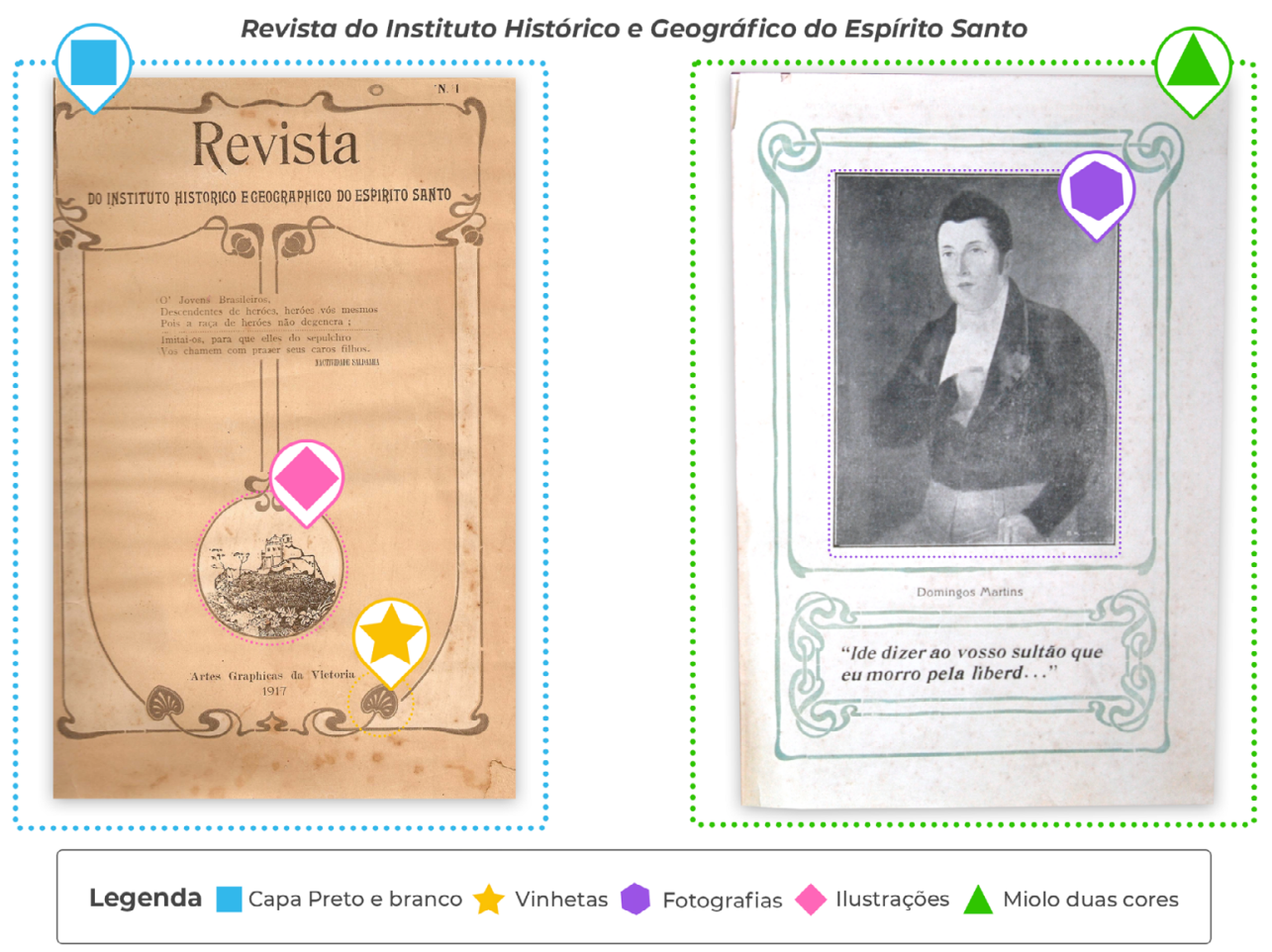

Como se observou na tabela 2 e nas figuras acima, foi possível identificar os aspectos gráficos das capas dos periódicos analisados, destacando a variação cromática e a presença de elementos como vinhetas, fotografias e ilustrações pictóricas. Assim, obteve-se que $50 \%$ possuíam capa preto e branco e $50 \%$ duas cores. Todas tinham algum tipo de elemento gráfico, sendo: $100 \%$ vinhetas decorativas; $50 \%$ fotografias e $75 \%$ ilustrações pictóricas.

Tabela 3: Informações das revistas da década de 1910.

\begin{tabular}{|c|c|c|c|c|}
\hline REVISTAS & PARQUE GRÁFICO & CIDADE & $\begin{array}{l}\text { NÚMERO DE } \\
\text { PÁGINAS }\end{array}$ & PREÇO \\
\hline A Verdade & Imprensa Estadual ${ }^{3}$ & Vitória & 42 & não consta \\
\hline $\begin{array}{l}\text { Revista Militar da } \\
\text { Força Pública do } \\
\text { Estado do Espírito } \\
\text { Santo }\end{array}$ & $\begin{array}{l}\text { Impr. Estadual - } \\
\text { Victoria }\end{array}$ & Vitória & 20 & Réis (R) 400 \\
\hline Victoria Illustrada & $\begin{array}{l}\text { Sociedade de Artes } \\
\text { Gráphicas de Vitória }\end{array}$ & Vitória & 28 & Réis (R) 400 \\
\hline $\begin{array}{l}\text { Revista do Instituto } \\
\text { Histórico e } \\
\text { Geográfico do } \\
\text { Espírito Santo }\end{array}$ & $\begin{array}{l}\text { Artes Graphicas da } \\
\text { Victoria }\end{array}$ & Vitória & 42 & não consta \\
\hline
\end{tabular}

${ }^{3}$ este dado foi obtido por meio de pesquisa bibliográfica, em Pereira (1927). 
Em relação a tabela 3, observou-se que $50 \%$ dos títulos eram pagos, todos tiveram sua produção na mesma cidade e parque gráfico, além de $50 \%$ terem mais de 40 páginas. Para análise comparativa entre os miolos das revistas, criou-se a tabela 4 , destacando sua construção baseada na estrutura das páginas e utilização tipográfica. Nesta análise, confrontou-se a composição gráfica do texto e dos títulos das matérias, não sendo incluídas as legendas das imagens e os anúncios.

Tabela 4: Análise dos miolos dos periódicos da década de 1910.

\begin{tabular}{|c|c|c|c|c|c|c|c|c|c|}
\hline \multirow[t]{3}{*}{ REVISTAS } & \multicolumn{9}{|c|}{ MIOLO } \\
\hline & \multicolumn{3}{|c|}{$N^{\circ}$ de colunas } & \multicolumn{4}{|c|}{ Alinhamento $^{1}$} & \multicolumn{2}{|c|}{ Tipografia e Lettering $^{2}$} \\
\hline & 1 & 2 & 3 & A & B & C & D & Lettering & Tipografia \\
\hline A Verdade & $x$ & $x$ & $x$ & & $x$ & & $x$ & $x$ & $x$ \\
\hline $\begin{array}{l}\text { Revista Militar da } \\
\text { Força Pública do } \\
\text { Estado do } \\
\text { Espírito Santo }\end{array}$ & $x$ & $x$ & & $x$ & $x$ & & $x$ & & $x$ \\
\hline Victoria Illustrada & $x$ & $x$ & & $x$ & $x$ & & $x$ & $x$ & $x$ \\
\hline $\begin{array}{l}\text { Revista do } \\
\text { Instituto Histórico } \\
\text { e Geográfico do } \\
\text { Espírito Santo }\end{array}$ & $x$ & $x$ & & & $x$ & & $x$ & & $x$ \\
\hline
\end{tabular}

${ }^{1} \mathrm{O}$ alinhamento foi dividido em 4 formas, sendo elas A (a esquerda), B (centralizado), C (a direita) e D (justificado). Fonte: Autores (2021).

Obteve-se, de acordo com a tabela 4, que todos os periódicos analisados tinham de uma a duas colunas de texto, apenas a revista $A$ Verdade usou, além dessas, três colunas. $O$ alinhamento centralizado foi utilizado em sua totalidade nos títulos das matérias e justificado no corpo de texto, além de utilizarem tipografia; $50 \%$ possuíam letterings, sendo a grande maioria empregado nos títulos. Em relação ao alinhamento dos textos, observou-se que $50 \%$ chegaram a ter até três formas de alinhamento, sendo a esquerda mais comumente vista em poesias e textos literários. 
Tabela 5: Relação de tipos de anúncios de acordo com sua com suas características.

\begin{tabular}{|c|c|c|c|c|c|}
\hline \multirow[t]{4}{*}{ REVISTAS } & \multicolumn{5}{|c|}{ TIPOS DE ANÚNCIOS } \\
\hline & \multicolumn{2}{|c|}{ IMAGÉTICO } & \multicolumn{3}{|c|}{ TIPOGRÁFICO } \\
\hline & & & \multicolumn{3}{|c|}{ Tipos de molduras } \\
\hline & $\begin{array}{l}\text { Ilustração } \\
\text { Pictórica }\end{array}$ & Fotografia & Ausente & Simples & Ornamentado \\
\hline A Verdade & não & não & não & não & não \\
\hline $\begin{array}{l}\text { Revista } \\
\text { Militar da } \\
\text { Força } \\
\text { Pública do } \\
\text { Estado do } \\
\text { Espírito } \\
\text { Santo }\end{array}$ & $\operatorname{sim}$ & não & não & $\operatorname{sim}$ & $\operatorname{sim}$ \\
\hline $\begin{array}{l}\text { Victoria } \\
\text { Illustrada }\end{array}$ & $\operatorname{sim}$ & $\operatorname{sim}$ & $\operatorname{sim}$ & $\operatorname{sim}$ & $\operatorname{sim}$ \\
\hline $\begin{array}{l}\text { Revista do } \\
\text { Instituto } \\
\text { Histórico e } \\
\text { Geográfico } \\
\text { do Espírito } \\
\text { Santo }\end{array}$ & não & não & não & não & não \\
\hline
\end{tabular}

Fonte: Autores (2021).

Na tabela 5 foi possível verificar a relação dos tipos de anúncios encontrados nas revistas, sendo que metade não apresentou nenhum e a outra metade chegou a ter ao menos uma das subcategorias presentes nos anúncios imagéticos e tipográficos. A seguir, na figura 24 , é possível visualizar um apanhado geral de todos os resultados encontrados nas tabelas acima apresentadas. 
Figura 24: Infográfico com os resultados encontrados.

\title{
REVISTAS CAPIXABAS INFOGRÁFICO
}

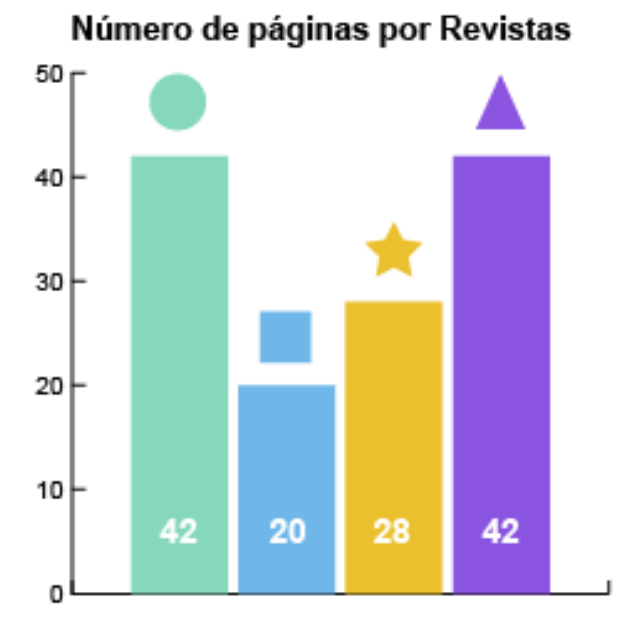

\author{
Variação Cromática da capa e do miolo
}
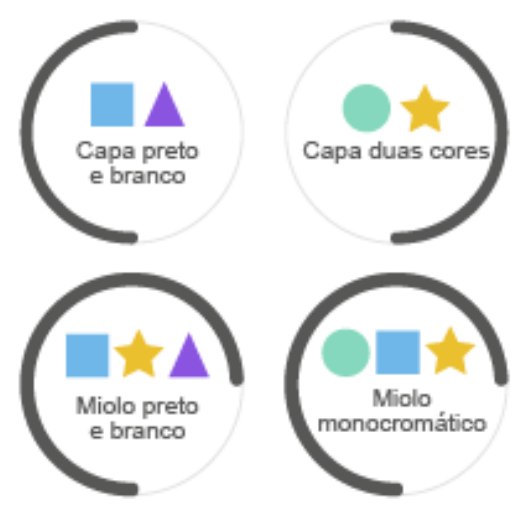
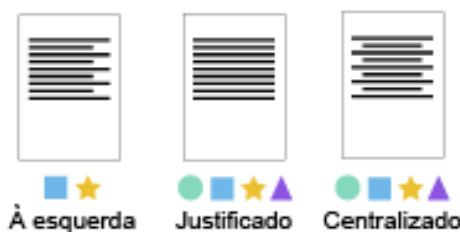

Formatos
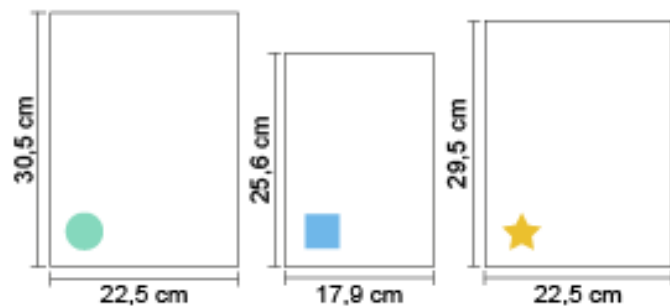

\section{Preço}

Réis (R) $400 \quad$ Nä̀ consta

\section{Anúncios}

\begin{tabular}{|ll|}
\hline Imagético & Tipográfico \\
\hline Im
\end{tabular}

Texto
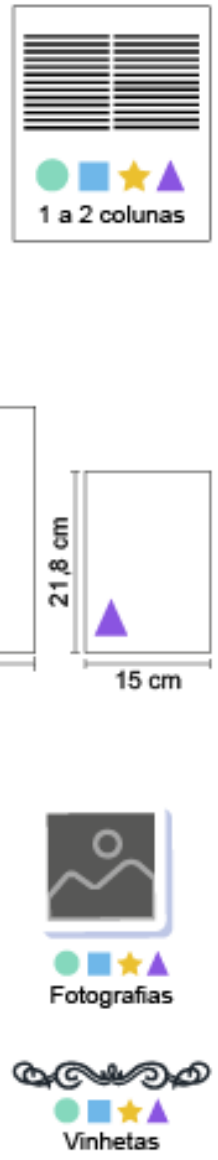

Revistas por acervo

BPES

APEES

$\mathrm{BC}$

ALES

USN

IFES

BPMVix

BPMC

\begin{tabular}{|l|l|}
\hline & Legenda \\
\hline & A Verdade \\
\hline & $\begin{array}{l}\text { Revista Militar da } \\
\text { Força Pública do } \\
\text { Estado do Espirito } \\
\text { Santo }\end{array}$ \\
\hline $\mathbf{1}$ & Victoria Illustrada \\
\hline $\mathbf{\Delta}$ & $\begin{array}{l}\text { Revista do Instituto } \\
\text { Histórico e Geográfico } \\
\text { do Espirito Santo }\end{array}$ \\
\hline
\end{tabular}


Ao final, pôde-se afirmar que as revistas possuíam identidade gráfica, apesar de termos poucos recursos tecnológicos disponíveis no ES na época. Ademais, a grande presença de elementos gráficos nas páginas das revistas pode estar relacionada à disponibilidade de recursos decorativos e vinhetas nos catálogos de tipos disponíveis na única oficina que atendeu a produção de todas elas. Além disso, notou-se o uso de molduras, tipografias e vinhetas decorativas em estilo art nouveau, denotando a busca por uma atualização estilística e pela integração da produção gráfica local ao estilo moderno e difundido mundialmente.

\section{Considerações finais}

A década de 1910 foi um período marcado pela gestão estadual dos Monteiros no Estado (Moreira \& Perrone, 2008). Neste período, a força militar estava em alta, fazendo-se presente nos periódicos como colaboradores, membros ou até tendo fotografias estampadas em suas páginas.

O governo tinha grande participação nos meios de comunicação, interessado em publicizar seus feitos e demonstrar o desenvolvimento do Estado. Um exemplo de revista que caracteriza bem essa fase é o periódico A Verdade, criado para marcar a visita do Presidente Hermes da Fonseca ao Estado, além de demonstrar os melhoramentos feitos na capital por Jerônimo Monteiro, com páginas cheias de experimentações, incluindo fotografias recortadas de personagens elitizadas compondo páginas de imagens das obras públicas.

Apesar de, nesta fase inicial, os recursos serem limitados e compartilhados, fato evidenciado pela presença de apenas um parque gráfico, as quatro revistas da década conseguiram apresentar um conteúdo diverso e uma configuração visual recorrente, que ditava o padrão de suas páginas. Além disso, houve investimentos em clichês para a impressão de imagens fotográficas e ilustrações pictóricas.

Os recursos gráficos encontrados eram reflexo do seu tempo, na medida em que o catálogo tipográfico disponível no parque gráfico ditou a estética da produção em um período em que o espaço em branco não era valorizado, com preenchimentos de áreas livres com vinhetas decorativas e molduras que suavizam o padrão ortogonal da composição dos blocos de tipos.

A importância desta análise está no entendimento do perfil das revistas, que refletem a imprensa capixaba da década. Foi possível correlacionar o contexto histórico com os usos de elementos gráficos, o perfil editorial e as tecnologias disponíveis, que juntos davam personalidade aos periódicos e ditavam o formato de apresentação das informações veiculadas. Além disso, cada uma das quatro revistas foi apresentada, destacando suas particularidades, e, ao final, foram realizadas análises comparativas entre elas, com os dados organizados em tabelas e infográficos, permitindo destacar características comuns e uso de recursos e técnicas recorrentes.

Após verificar separadamente cada título da década, pode-se chegar à conclusão que foi um período marcado pela política, em que metade dos títulos eram desta temática, enquanto os outros, apesar de não se centrarem nesta tipologia, fazem ao menos uma menção, em seu 
miolo, às figuras políticas como Jerônimo Monteiro ou militares da época, com destaque especial para a Revista Militar da Força Pública do Estado do Espírito Santo.

A pesquisa apresentou as revistas capixabas publicadas na década de 1910, contribuindo para a história do design no Espírito Santo e para o desvelar da memória gráfica capixaba. Espera-se abrir espaço para discussões e futuras análises de outros pesquisadores.

\section{Referências}

A Verdade (1912), Vitória, s/n.

Azerêdo, J. S., \& Fonseca, L. P. (2016). Análise dos anúncios da revista Chanaan. In: Congresso Brasileiro de Pesquisa e Desenvolvimento em Design, 12, p. 382-394, 2016. Anais. São Paulo: Blucher Design Proceedings, v.9, n.2.

Fonseca, L. P., Gomes, D. D. \& Campos, A. P. (2016). Conjunto Metodológico para Pesquisa em História do Design a partir de Materiais Impressos. Revista Brasileira de Design da Informação, São Paulo, v. 13, n. 2, p. 1 - 19.

Matos, K. T., Santos, M. N., \& Nascimento, B. B.; Fonseca, L. P. (2009). Metodologia para inventário de revistas. Revista Brasileira de Design da Informação, São Paulo, v. 16, n. 3, p. 456-466.

Mattedi, J. C. (2005). História da Imprensa Oficial do Espírito Santo. Vitória: [s.n].

Meggs, P. B., \& Purvis, A. W. (2009). História do design gráfico. São Paulo: Cosac Naify.

Moreira, T. H., \& Perrone, A. (2008). História e Geografia do Espírito Santo. 9. Vitória: Gráfica Sodré.

Munteal, O., \& Grandi, L. (2005). A imprensa na história do Brasil: fotojornalismo no século XX. Rio de Janeiro: Ed. PUC-Rio: Desiderata, 200 p.

Pacheco, H. S., Barbosa, G., \& Santos, P. F. R. (2011). Impressões entre a tradição e a modernidade. Revista do Instituto Histórico e Geográfico do Espírito Santo, Vitória, v. 66, p. 235-251.

Pereira, H. A. (1927). A imprensa no Espírito Santo, in Revista do Instituto Histórico e Geográfico do Espírito Santo, VI. Vitória.

Porta, F. (1958). Dicionário de artes gráficas. Rio de Janeiro: Globo.

Revista do Instituto Histórico e Geográfico do Espírito Santo (1917), Vitória, ano 1, n. 1.

Victoria Illustrada (1914), Vitória, ano 1, n. 4, fev. 1914.

\section{Sobre o(a/s) autor(a/es)}

Amanda Martinelli das Neves, Bacharel, UFES, Brasil, <amandamartinelli2015@gmail.com> Letícia Pedruzzi Fonseca, Dra., Ufes, Brasil, <leticia.fonseca@ufes.br> 